\title{
Rosja i Polska - „domowy spór" Słowian czy konflikt mentalności?
}

\author{
Aleksander W. Lipatow
}


nAPTS Seria VI 2000

\section{Aleksander W. Lipatow}

\section{Rosja i Polska — „domowy spór” Słowian czy konflikt mentalności?}

$\mathrm{H}$

istoryczna konfrontacja Rosji i Polski, interpretowana w kategoriach interesów państwowych, ideologii narodowych i konfesji, ulegała komplikacji - szczególnie w Rosji - poprzez ujęcie problematyki polsko-rosyjskiej w karby koncepcji wspólnoty słowiańskiej ${ }^{1}$. W ten sposób rozbieżność i bliskość sąsiadów geograficznych była włączana w obszerniejszy — uniwersalny — kontekst Słowiańszczyzny, jako szczególnej, wyodrębnionej części Europy. Stąd stosunek Aleksandra Puszkina - poety i historyka - do powstania listopadowego oraz sposób traktowania przez niego konfrontacji rosyjsko-polskiej ${ }^{2}$. Stąd jego Oszczercom Rosji - riposta patriotyczna Europie, oburzonej okrutnym stłumieniem polskiego zrywu niepodległościowego.

Dla Puszkina - a była to wypowiedź odbijająca charakterystyczne nastroje przeważającej części tych Rosjan, którzy należeli do społeczeństwa państwowego - polskie powstanie to „domowy spór" Słowian. Stąd postawa: wara wam, zachodni oskarżyciele, od drzwi naszego wspólnego domu. Dwa największe mocarstwa słowiańskie, Polska i Rosja, od zarania dziejów walczyły o przywództwo w Słowiańszczyźnie. Polska ten spór historyczny przegrała. Musi więc uznać pierwszeństwo Rosji i wspierać ją we wspólnej sprawie tworzenia potężnej i prężnej wspólnoty słowiańskiej wobec wyzwania wspólnoty zachodniej.

\footnotetext{
${ }^{1} \mathrm{Na}$ temat tej koncepcji por: A. W. Lipatow, Wspolnota slowiańska: historyczne reinkarnacje i metodologiczne interpretacje idei, w: Wielkie mity narodowe Stowian, Poznań 1999; idem, Slowiańska wspótnota: prawda historyczna i mit idologiczny, w tegoż, Stowiańszczyzna - Polska - Rosja, Izabelin 1999.

2 Por. A. W. Lipatow, Mickiewicz i Puszkin: obraz na tle historiografii i historiozofii, tł. M. Prussak, „Teksty Drugie” 1998 nr 5, s. 211-219.
} 
Ten typ rosyjskiego myślenia, łączący pierwiastki lokalnego nacjonalizmu i słowiańskiego uniwersalizmu na ideologicznym fundamencie wszechnarodowej mocarstwowości Rosji, ukształtował mentalność rosyjskiego społeczeństwa państwowego. Stąd poprzez pryzmat owej mentalności jako czynnika prymarnego można wyjaśnić konflikty dziejowe rosyjskości i polskości, jak zresztą komplikacje w stosunkach państwa rosyjskiego, sowieckiego i postsowieckiego $z$ narodami wewnątrz i na zewnątrz swoich granic.

Brak wyważonej polityki narodowościowej wewnątrz i na zewnątrz państwa to charakterystyczna cecha dziejowa wielonarodowej Rosji, co wywodzi się $z$ systemu rządów oraz permanentnego zamykania się na zewnątrz celem osiągnięcia zwartości wewnętrznej. „Carstwo rosyjskie" było - jak jeszcze w XVI wieku stwierdził książę Andrzej Kurbski „zamknięte jakby w piekielnej twierdzy" ${ }^{3}$. Ten system rządzenia, modyfikowany $z$ upływem czasu, ale ciągle oparty na niezmiennych założeniach imperialnych i wynikających stąd zasadach myślenia politycznego, charakterze i sposobach funkcjonowania instytucji państwowych oraz stosowanej socjotechniki, da się prześledzić od — używając określenia Jana Kucharzewskiego - białego caratu do czerwonego, zaś w pewnym stopniu również w mentalności i sposobach działania postsowieckiej elity władzy.

Rosyjska polityka narodowościowa wychodziła $z$ ściśle rosyjskich, własnych, Rosjan i Rosji dotyczących tradycji powstawania i rozbudowy najpierw Państwa Moskiewskiego, potem Imperium Rosyjskiego, następnie ZSRR oraz Rosji postsowieckiej. I nie tylko wychodziła, ale i wręcz polegała na nich. Stąd wszystkie owe luki i braki w państwowej polityce wobec innych narodów, zaś czasem faktyczne jej nieistnienie od czasów dawnych po dziś dzień.

Samo powstanie państwa było interpretowane jako „zbieranie ziem ruskich”. To używane do chwili obecnej, wzniosłe określenie jest z natury swojej ideologiczne, nie zaś historiograficzne: ziemie ruskie byly nie zbierane, lecz podbijane przez księstwo moskiewskie. Podbijane nie tylko terytorialnie: wraz z podbojem unicestwiano, i to zazwyczaj krwawo, lokalne prawo zwyczajowe oraz lokalny system ustrojowy, i to często wraz z miejscową elitą. W ten sposób niszczono resztki demokratycznych tradycji starożytnej Rusi, zachowanych z czasów sprzed najazdu mongolskiego. Okrutna likwidacja republik miejskich Nowogrodu i Pskowa, słowiańskich odpowiedników ówczesnych republik miejskich na Zachodzie, była ostatnim etapem owego „zbierania ziem ruskich”, zakończonym masową deportacją znaczących mieszkańców. (To ostatnie posunięcie stało się tradycyjnym środkiem polityki caratu, a następnie bolszewizmu, czego doznali bynajmniej nie tylko i wyłącznie Polacy).

W ten swoisty sposób dokonywał się we wschodniej części Europy, naturalny dla historii owych czasów, proces tworzenia się centralistycznej władzy monarchii absolutystycznych. Księstwo moskiewskie wykorzystywało jednak dodatkowo, doznane na własnej skórze, doświadczenia despotyzmu wschodniego $z$ lat najazdu mongolskiego, niszcząc przy tym własne historycznie i etnicznie doświadczenia Rusi sprzed tego najazdu. A więc określenie

\footnotetext{
${ }^{3}$ Pieriepiska Iwana Groznogos Andriejem Kurbskim, Leningrad 1979, s. 110.
} 
„zbieranie ziem ruskich” tylko umownie odpowiada początkowemu stadium kształtowania się Państwa Moskiewskiego. Właśnie wtedy były „zbierane” przeważnie ziemie ruskie. Ale już wtedy zaczęto „zbierać" także ziemie niedawnych zaborców: chanat kazański i astrachański, po czym przyszła kolej na Ural, Syberię etc.

Absolutyzm moskiewski, w odróżnieniu od zachodniego, był totalny. Odmienił on nie tylko ksztalt zewnętrzny, czyli granice ziem ruskich. Stopniowo przemienial także podbite ziemie również wewnętrznie, na swoją modłę kształtując duszę rosyjską, formując mentalność narodową na drodze zapoczątkowanej przez okres niewoli mongolskiej. Duchowy bunt Andrzeja Kurbskiego (który znalazł schronienie w kraju demokracji szlacheckiej) przeciwko tyranii Iwana Groźnego był przejawem tradycjonalizmu — niszczonej tradycji demokracji staroruskiej, polemiką z współczesnym i historycznie obcym Rusi absolutyzmem. Ale to właśnie ten absolutyzm po zwycięstwie nad starą tradycją tworzył nową, która dotąd dominuje w mentalności rosyjskiej. Upańszczyźnienie większej części narodowości, absolutne uzależnienie szlachty od władzy cara i sakralizacja jego osoby i jego władzy ${ }^{4}$ - to wszystko, tworząc podwaliny administracyjnej i duchowej tyranii już w bliskiej perspektywie historycznej, dało początek społeczeństwu państwowemu. Paternalizm jako skutek zaślepionego poddania się woli cara i wiary w niego jako w najwyższą instancję na ziemi, niewolnicze posłuszeństwo wobec władzy jako skutek zniewolenia umysłu, a poprzez to bierne pokładanie nadziei na los, brak inicjatywy, stłumienie pierwiastków indywidualizmu — to wszystko, równolegle $z$ systemem rządów sekularnych, było wszczepiane w świadomość mieszkańców poprzez związaną z caratem Cerkiew prawosławną z jej dogmatem soborności, Cerkiew, która od czasów Piotra I stała się przybudówką państwa, komórką państwową, istniejąca w tym charakterze do naszych dni.

Zależność władzy duchownej od świeckiej i szczególna rola władcy wiąże się z przynależnością Rosji do bizantyńskiego kręgu kulturowego. W związku z tym mentalnościowe różnice Rosjan i Polaków nader trafnie ujął Mickiewicz, który doskonale poznał Rosję od środka: „Służymy tak bogu, jak Moskale służą carowi”.

Po podboju tureckim Bizancjum utraciło zarówno byt państwowy, jak rolę energicznego ośrodka kulturowego. Wybitny historyk rosyjski Kluczewski zauważył, że Ruś wiele zawdzięcza Bizancjum, jednak również stamtąd przyszło do nas owo „wierzyć, nie myśleć”. Dlatego możliwa była negacja myślenia racjonalistycznego, stąd jeszcze w wieku XVII Cerkiew występowała przeciwko nauczaniu geometrii, gdyż tu rozumowanie zastępuje wiarę. Bizantynizm bez Bizancjum w rosyjskim życiu państwowym nieuchronnie stawał się tradycją zwróconą w kierunku przeciwnym do historii Europy. Ażeby zaś wejść w europejską współczesność, Państwo Moskiewskie musiało stworzyć przesłanki wewnętrzzne, które by dały początek wspólnej płaszczyzny spotkania z dynamicznie rozwijającym się światem łacińskim.

${ }^{4}$ Zob. B. Uspienski i W. Żywow, Car i Bóg, tt. i wst. H. Paprocki, Warszawa 1992.

${ }^{5}$ A. Mickiewicz, Dzieła wszystkie. Wydanie sejmowe, t. 16, Warszawa 1933, s. 219. 
Pod tym względem znamienne są kontakty Iwana III z cesarzem Fryderykiem III i papieżem Pawłem II. Książę moskiewski (który niebawem obwołał się panem Wszechrusi) w konsekwencji tych kontaktów zawarł ślub z wychowaną w Rzymie córką ostatniego cesarza bizantyjskiego Zofią. Córka Iwana wyszła za wielkiego księcia litewskiego, przyszłego króla Polski Aleksandra, a do wzniesienia nowych budowli na Kremlu zaproszono mistrzów włoskich.

Dążenia ku wejściu w obręb świata zachodniego kontynuował Iwan IV Groźny, który w tym celu chciał nawet ożenić się z królową angielską. O dojrzewaniu wśród rosyjskiej elity koncepcji otwarcia własnego bizantynizmu na świat świadczy między innymi to, że w 1595 roku car Borys Godunow zamierzał stworzyć w Moskwie pierwszy uniwersytet, dokąd planował zaprosić profesorów niemieckich. Temu pomysłowi sprzeciwiła się Cerkiew, dowodząc, że łacina na równi z językiem tatarskim zaprowadzi ludzi prawosławnych pod władzę szatana. Ale proces okcydentalizacji był nieuchronny ze względu na interesy państwa i uzyskał szczególną dynamikę rozwojową w następnym stuleciu, kiedy pod tym względem wyjątkowa rola przypadła Polsce.

W tym okresie jednocześnie współgrały czynniki odgórne (polityka i kultura dworska, wchłaniająca wzory polskie często za pośrednictwem prawosławnych ukraińsko-białoruskich współwyznawców), jak również oddolne: wskutek bezpośredniego zetknięcia się z polskością w czasach Smuty i późniejszych starć z Rzecząpospolitą ${ }^{6}$. Wpływy sarmackie w kulturze popularnej odbiły się w rozpowszechnieniu zarówno polskiej mody, jak polskich facecji, żartów, wątków powieściowych oraz pieśni. Symeon Połocki po przyjeździe do Moskwy zanotowal, że śpiewa się pieśni polskie, czasem nawet po polsku nie rozumiejąc ich sensu, ale „podnosząc się na duchu” ". Niezwykła popularność polskich pieśni jest udokumentowana pokaźną ilością zachowanych rękopisów XVII-wiecznych i z pierwszych dziesięcioleci XVIII wieku ${ }^{8}$. Urzekała odbiorców i nowa melodyka, odrębna od folkloru rosyjskiego, i sama treść - inna niż tutejsza elegancja obyczajów i przeżyć. Kultura wysoka natomiast wchłaniała model polskiej poezji sylabicznej, przyswajała polskie poetyki i retoryki oraz spadek antyku grecko-rzymskiego w kształcie przyswojonym i oswojonym przez literaturę polską.

W obydwu płaszczyznach (kultury wysokiej i kultury popularnej) odbiór polskości był szczątkowy: nowe wzory ujmowano zewnętrznie - w swoich kształtach widzialnych. $\mathrm{Na}$ odbiór wewnętrzny — adekwatne rozumienie treści związanych z indywidualizmem i sposobem myślenia, cechującym społeczeństwo obywatelskie — Rosjanie nie byli przygotowani umysłowo ani emocjonalnie. W despotycznym Państwie Moskiewskim, wykluczającym istnienie społeczeństwa obywatelskiego, republikanizm był zupełnie obcy i całkowicie niezrozu-

\footnotetext{
${ }^{6}$ Por. Istorija litieratur zapadnych i jużnych stawian, Moskwa 1997; A. W. Lipatow, Zmiana paradygmatów: od średniowiecza ku literaturze nowożytnej, „Barok” 1996 III/2 (6), s. 115-129.

7 S. Polocki, Izbrannyje proizwiedienija, Moskwa-Leningrad 1953, s. 213.

${ }^{8}$ A. Pozdniejew odnalazł ponad 500 rosyjskich i ponad 100 ukraińskich zbiorków rękopiśmiennych, które dokładnie zbadał. Zob. między innymi jego rozprawę Swietskije polskije piesni w russkich rukopisnych piesiennikach XVII w. w: Polsko-russkije swiazi, Moskwa 1970.
} 
miały w tekstach literackich. Ale odbiór „zewnętrzny”, czyli zauroczenie „pokrywą” polskości i „przeoczenie” jej „jądra”, stworzył zarazem sytuację, kiedy Muzy były silniejsze od Marsa. Wbrew konfliktom państwowym i animozjom konfesyjnym Polska od tamtych właśnie czasów przyciąga Rosjan. Tu znaleźć można początki, trwającej do dziś i niewytłumaczalnej dla polskiej pamięci społecznej, nieodwzajemnionej miłości Rosjan do Polski.

Od czasów gwałtownych i bezwzględnych wobec tradycyjnej kultury i obyczajowości rosyjskiej, odgórnych reform Piotra I społeczność rosyjska, jej kultura i mentalność ulegaja rozdwojeniu, którego skutki odczuwamy również współcześnie. Zorientalizowany model swojski i zokcydentalizowany model nowoczesny boleśnie rozcięły organizm państwowy, społeczny, kulturowy, samo życie codzienne i historyczne narodowości rosyjskiej. Uświadomienie skutków tego rozdwojenia, próby porozumienia i scalenia, rozpoczynające się od końca lat dwudziestych XXX wieku (okcydentaliści i słowianofile), trwają nadal, odzwierciedlając proces kształtowania się samoświadomości wciąż unowocześniającej się Rosji. W tym właśnie kontekście stosunku Rosji do Zachodu kryją się korzenie zróżnicowanego stosunku Rosjan do Polski - zróżnicowanego, albowiem zróżnicowaniu od czasów Piotra I uległa narodowość rosyjska, jej kultura oraz mentalność, a co za tym idzie - historyczne ukierunkowanie i styl myślenia samoidentyfikującego.

Piotr, jako despota w tradycyjnym już stylu moskiewskim, tworząc imperium europejskie uświadomił wszystkim, na podstawie własnych i bezpośrednich doświadczeń okcydentalnych, że do realizacji jego wielkich zamiarów potrzebna jest nie tylko zewnętrzna zmiana kształtu państwa i państwowości, ale również wewnętrzna rosyjskiej duszy i kultury. Dlatego przedsięwziął w barbarzyński sposób totalne wprowadzanie nowego modelu oświaty, obyczajowości, a nawet mody. Miało to stworzyć osobowość, jednostkę obok i wbrew tradycyjnej soborności, albowiem tylko indywiduum może wykazywać inicjatywę, niezbędną przy kształtowaniu Rosji zwracającej się na Zachód. Ale despota moskiewski, stając się imperatorem petersburskim, równocześnie pozostawał Rosjaninem — oto przyczyna ambiwalencji, cechującej stworzoną przezeń nową rzeczywistość. Wola jednostki, jej inicjatywa i ukierunkowanie działalności były wytyczane i konstruowane przez carską osobę najwyższą — jednocześnie świecką i sakralną.

Niemniej stworzona symbioza bizantynizmu i łacińskości, wraz z wprowadzeniem wzorców zachodniej kultury i systemu nauczania, nieuchronnie dawały przesłanki stopniowego powstawania zalążków społeczeństwa obywatelskiego w łonie zmodernizowanego społeczeństwa państwowego. Radiszczew i Nowikow w czasach Katarzyny II (która posąiem , jeźdźca miedzianego" wskazała swój wzór władcy rosyjskiego) unaoczniają zarówno powstanie płytkiej jeszcze warstwy społeczeństwa obywatelskiego, jak również pierwsze objawy zaistnienia inteligencji rosyjskiej, poza rosyjskim tradycjonalizmem i zokcydentalizowaną rosyjską despotią, a zarazem przeciw nim.

W tej właśnie warstwie społeczeństwa obywatelskiego i w tymże środowisku inteligencji tradycyjny już dla Rosji „polonizm” uzyskał nowy, tym razem pełny już wymiar. Wraz 
z powstaniem wspólnej płaszczyzny społeczeństwa obywatelskiego (na podstawie niezależnego myślenia jednostki) polskość stała się pociągająca dla rosyjskości już nie tylko, jak przedtem, estetycznie, ale również pod względem obywatelskim, zwłaszcza w postaci szlacheckiej demokracji i ukształtowanych przez nią cech społeczności polskiej. Właśnie to zjawisko dokumentuje niejako przyszły dekabrysta, poeta Konrad Rylejew, w liście do Juliana Ursyna Niemcewicza, urzeczony tak jego osobowością uczestnika powstania Kościuszki i „przyjaciela Washingtona”, jak i dźwiękami jego „sarmackiej lutni” 9 . To również przyciąga innego dekabrystę, poetę Aleksandra Bestużewa. "Jestem zupełnie zadowolony z poezji polskiej” - pisał w liście do matki. „Oddycha patriotyzmem, a wymysł przebiera się często w szaty nowych myśli i trafnych zwrotów. Ucząc się dalej polskiego, wydobywam nowy kruszec dla języka rosyjskiego" 10 .

A więc rozdwojenie kulturowe Rosji uwarunkowało rozdwojenie rosyjskiego stosunku do Polski i odbioru polskości. K. Rylejew, A. Bestużew, P. Wiaziemski, S. Sobolewski, A. Turgieniew (jeżeli chodzi o okres początkowy) to nie tylko polonofile i nie po prostu polonofile. Przede wszystkim to są przedstawiciele społeczeństwa obywatelskiego, i stąd właśnie bierze się ich polonofilstwo, albowiem w ich czasach — w odróżnieniu od wieku XVII - w Rosji były obecne i przeważały już inne, zachodnioeuropejskie wzorce kultury i sztuki. Ale polska literatura, polska tradycja historyczna, polski odbiór świata - to wszystko, co odbiło się w mentalności polskiej, przyciaggało tych Rosjan, albowiem wiązało się bezpośrednio z polskim modelem społeczeństwa obywatelskiego, ukształtowanym przez system demokracji szlacheckiej (co zresztą mogło kojarzyć się z dawnym, ruskim modelem demokracji, zdławionym przez Księstwo Moskiewskie).

Natomiast jeżeli chodzi o społeczeństwo i kulturę popularną, da się zaobserwować pewną ewoluującą ciągłość. Początkowe zewnętrzne zauroczenie polskością, wędrujące z kultury wysokiej do obiegu popularnego, najpierw podświadomie, później — od końca XVII wieku - coraz świadomiej stawało się przejawem wewnętrznej potrzeby wydostania się poza ograniczenia własnego, przeciągającego się średniowiecza. Było to pragnienie przekroczenia granic tradycyjnego bizantynizmu — poza polityką, niezależnie od polityki, albo więcej: wbrew oficjalnej polityce państwa wobec Polski, wbrew oficjalnemu nastawieniu Cerkwi prawosławnej wobec katolicyzmu.

Przejawiało się to dążenie w modzie (która w istocie swojej jest irracjonalna i apolityczna) oraz w racjonalnej (jeżeli chodzi o podstawy) kulturze wysokiej. W miarę okcydentalizacji części kultury rosyjskiej, na przestrzeni wieku XVIII polska kultura staje się jednym z partnerów, nie zaś wyłącznie - jak przedtem - wzorcem. Aczkolwiek i wzorcem również (przykłady: Śpiewy historyczne Niemcewicza a Dumy Rylejewa, muzyka polska, wreszcie arystokratyczne środowisko polskie, które stopniowo stworzyło w Petersburgu wpływową

9 Tekst listu w: A. Kraushar, Obrazy i wizerunki historyczne, Warszawa 1906, s. 330.

${ }^{10}$ Pamiatniki diekabristow, t. 1, Leningrad 1926, s. 30. 
enklawę, oraz również szlachta polska, która po rozbiorach i powstaniach weszła w kontakt bezpośredni z żywiołem rosyjskim).

Kontakty bezpośrednie w sferze kultury ciągle łączyły Rosjan z Polakami, sprzyjając lepszemu ich rozumieniu. Równocześnie polityka oficjalna ciągle ich dzieliła i rozłączała.

Równolegle powstałe już rosyjskie społeczeństwo obywatelskie, wbrew rosyjskiemu społeczeństwu państwowemu, przyswajało polskość poprzez kulturowy właśnie, nie zaś upolityczniony jej odbiór. Stąd głębsze rozumienie Polski i Polaków właśnie w tym środowisku. A więc jeżeli przed ukształtowaniem społeczeństwa obywatelskiego kultura polska była odbierana w jej przejawach zewnętrznych, to później również w jej przejawach wewnętrznych, czyli w jej istocie, poprzez zrozumienie innej mentalności narodowej. Zarówno przedtem, jak i później w ramach społeczeństwa państwowego taki odbiór był, pozostawał i po dziś dzień pozostaje niemożliwy, bo niezrozumiały ze względu właśnie na istotę takiego społeczeństwa, historycznie ukształtowanego i nadal współodtwarzanego przez system rządzenia oraz wytyczaną przezeń politykę wewnętrzną i zewnętrzną. Polska zaś od czasów rozbiorów staje się przedmiotem zarówno polityki wewnętrznej, jak zewnętrznej, a Polacy częścią ludności zarówno wewnątrz, jak i na zewnątrz Rosji.

To polityka zaczęła komplikować stosunek do Polski i Polaków w rosyjskim społeczeństwie państwowym. Stało się to i nasilało w okresie, kiedy Polska z części świata zewnętrznego stała się częścią świata wewnętrznego Rosji. Ta wewnętrzna część Imperium, która nie życzyła sobie przejmować obyczaje, ulegać wymaganiom, naśladować tryb życia Rosji, czyli odpychała to wszystko, co ukształtowało mentalność rosyjskiego społeczeństwa państwowego i pielęgnowane było przez system rządów, ta właśnie polska reakcja obronno-negatywna wywoływała rozjątrzenie elity władzy i irytację społeczeństwa państwowego. Ujawniała się ukryta w naturze ludzkiej opozycja kultury i natury. Wyrywał się na powierzchnię życia społecznego zakodowany stosunek „swojego” do „obcego”, nasilany przez przekonanie, że ten narodowo „obcy”, będąc państwowo „swoim”, nie chce z taką „swojskością” się utożsamiać, nie chce się z tym „wspólnym”, czyli rosyjsko-państwowym, identyfikować.

Ów brak chęci Polaków do życia zgodnie z wymaganiami rosyjskiej państwowości i rosyjskiej mentalności wywoływał w społeczeństwie państwowym irytację, w rodzaju sakramentalnych pytań, wygłaszanych od czasów Imperium po czasy „obozu krajów socjalistycznych ze Związkiem Radzieckim na czele”: „Czego właściwie oni potrzebuja?” albo „Dlaczego nie mogą żyć tak, jak my?”. W tych pytaniach, prócz szczerego albo udawanego - ideologicznie słusznego - niezrozumienia, ujawniał się niezamierzenie mniej czy bardziej uświadamiany rosyjski kompleks niższości: „myśmy się pogodzili z niewolą i poniżającym godność ludzką poziomem życia, a oni zawsze chcą być lepsi”.

W takich reakcjach rosyjskich na "polską krnąbrność, „polską wyniosłość”, „polską pychę”, ,polskie knowania” odzwierciedla się nie tylko różnica mentalności narodowych, ale i stopień dojrzałości własnej identyfikacji. 
Formowanie się polskiej mentalności jest ciągłe i zwarte. Wynika z tego wyraźny kształt i sam trzon polskiej samoidentyfikacji. Natomiast w wyniku kilkakrotnie przerywanej ciągłości historycznej (najazd mongolski, państwo moskiewskie, imperium Piotra I, ZSRR, Rosja postradziecka) oraz rozdwojenia kultury rosyjskiej (trwającego od czasów Piotra I do naszych czasów) rosyjska mentalność — zgodnie z badaniami etnologicznymi — dotychczas jest krucha, niepewna i płochliwa, zaś samoidentyfikacja niewyraźna i niedookreślona.

To właśnie powoduje zarówno krańcowość sławetnej „duszy rosyjskiej”, jak sięganie po ordynarną siłę jako środek rozwiązywania wszelkich problemów. Da się to zaobserwować od początków (zdławienie Nowogrodu przez Państwo Moskiewskie i masowa deportacja ludności) poprzez czasy Imperium (zdławienie polskości i zsyłka Polaków), następnie czasy ZSRR (najazd na Polskę w 1939 roku i wywózki Polaków do Azji Środkowej i na Syberię) aż po czasy Rosji postsowieckiej: rozstrzelanie własnego parlamentu jako środek utrwalania demokracji albo druga już wojna z Czeczenią jako metoda rozstrzygania kwestii narodowościowych. Jednocześnie są to przykłady trwałej dominacji społeczeństwa państwowego, które zgodnie $\mathrm{z}$ prawidłowościami sprzężenia zwrotnego jest rzutowaniem systemu rządów na płaszczyznę społeczną. Stąd inercyjne trwanie doświadczeń z czasów Państwa Moskiewskiego. Zdobycie (czyli według wspomnianego wcześniej, wzniosłego określenia oficjalnej historiografii, „zbieranie”) ziem ruskich siłą, a następnie ich konsolidacja państwowa na wspólnej podstawie narodowej i wyznaniowej, na dłuższą metę nie mogły dać takich samych rezultatów w stosunku do innych podbijanych narodów, o innej tradycji kulturowej i odmiennych wyznaniach. Niemniej wobec nich były też stosowane podobne środki, zaś ruchy narodowowyzwoleńcze dławiono tak samo, jak bunty własnych chłopów albo Kozaków.

Z Polską władze rosyjskie w swojej praktyce inercyjnie postępowały tak samo, jak wobec innych narodów, albowiem czynnikiem sprawczym takiego postępowania była już ukształtowana tradycyjna mentalność „zbieraczy ziem” i narodów mocnej ręki, co znalazło odbicie w żywym po dziś dzień porzekadle: Sita jest', uma nie nado („Kiedy jest siła — rozumu nie trzeba”).

Mentalność taka, jak szory założone na bojowego konia imperium, uniemożliwiała zrozumienie tego, że po pierwsze Polska to kraj o wielkiej historii i o wiele dłuższej niż w Rosji ciągłości własnej państwowości, a co za tym idzie — wysokiej kulturze politycznej, a po wtóre, że Rzeczpospolita, należąc do zachodniego kręgu kultury europejskiej, jednocześnie dość gruntownie odróżnia się od większości krajów zachodnich swoim ustrojem republikańskim, zaś przez to - mentalnością narodową.

Królestwo Kongresowe nie było zdobyte, lecz przyłączone do Rosji w wyniku międzynarodowych układów, a więc i zobowiązań, co nadawało szczególny status Królestwu w ramach Imperium. Jednak w praktyce imperialnej status ten nie był przez władze rosyjskie honorowany, albowiem działała tradycja mentalnościowa: w kraju — w odróżnieniu od tej części Europy, gdzie znano prawo rzymskie - ongiś i teraz rozumowanie polega nie na założeniach prawnych, lecz wewnętrznym odczuciu sprawiedliwości. Była to w rozumieniu władz wyłącznie sprawiedliwość w sprawie rosyjskiej, dlatego administracja nie mogła ogar- 
nąć specyfiki polskiej, z przewidywalnymi skutkami pogwałcenia praw (do których Polacy nawykli) oraz również przewidywalnymi konsekwencjami zniewagi tradycji i obrazy dumy narodowej Polaków. Można powiedzieć, że niezamierzonym powodem kolejnych powstań polskich była indolencja władz rosyjskich w zakresie polityki narodowościowej. Jednym z przykładów może służyć przemówienie Mikołaja I w październiku 1835 roku do deputacji warszawskiej w Łazienkach, kiedy car autorytatywnie i twardo stwierdził, że Polacy muszą dowieść absolutnym posłuszeństwem, iż zasługują na miano rosyjskich poddanych, inaczej Warszawa będzie zrównana z ziemią.

Nie wysnuto zatem żadnych wniosków z powstania listopadowego. Dalsze tradycyjne postępowanie władz nadal współtworzyło tradycje polskich powstań ${ }^{11}$.

W dziejach rosyjskiej państwowości brak właściwego podejścia do specyfiki narodowej, opartego na rozeznaniu mentalności społeczeństwa, wobec którego tworzy się politykę narodowościową, trwa po dziś dzień. Najświeższym świadectwem takiego stanu rzeczy jest wspomniana wcześniej druga wojna czeczeńska w przeciągu niespelna dziesięciu lat istnienia Rosji mieniącej się „demokratyczną”.

Elita władzy zawsze nadaje kierunek myślenia społeczeństwu państwowemu i zarazem myślenie to odzwierciedla. Lecz z powodu rozdwojenia kultury rosyjskiej, o czym była mowa powyżej, myślenie to nie jest jednolite. Filozof rosyjski G. Fiedotow (1886-1951) stwierdził, że po reformach Piotra I naród rosyjski stracił sposobność pojmowania własnego państwa. I owszem, trwa to po dziś dzień. Ze względu na wielonarodowe części składowe kraju samo określenie „rosyjski” jest nieostre, albowiem nie posiada ani konkretności etnicznej, ani lokalnej, ani językowej. Wszystko to sprawia, że „pas transmisyjny” między władzą a społeczeństwem państwowym jest obwisły i ślizga się na kołach przewodowych. Tak obok posłusznego wchłaniania antypolskich sloganów propagandowych stale istnieje ukryte zauroczenie polskością. Może ono ujawniać się negatywnie — w jawnych formach agresji: gniewa i jątrzy to, że Polak może sobie pozwolić na to, czego nie wolno „patriocie rosyjskiemu”, który podświadomie jest niewolnikiem ślepej i obowiązkowej wiary w cara i państwo. Może też uzewnętrzniać się pozytywnie - w niekontrolowanym zachwycie, uniesieniu, oczarowaniu żywiołowym urokiem piękna polskości, kiedy to irracjonalna reakcja wymyka się racjonalnej - zideologizowanej kontroli wewnętrznej i zewnętrznej. Jednym z jaskrawszych przykładów jest tak zwana "polska scena" w pierwszej rosyjskiej operze romantycznej $\dot{Z}$ ycie za cara Michała Glinki ${ }^{12}$. Oto już w przeciagu ponad póltora wieku widownia po podniesieniu kurtyny wybucha żywiołowymi oklaskami na widok polskich strojów, polskiej postury, polskich gestów i towarzyszącym temu malowniczemu obrazowi dźwiękom poloneza.

Ta żywiołowa reakcja stała się tradycją czy też zwyczajem: pociągający urok polskości wciąż Rosjan porywa i to do tego stopnia, że widzowie nie zdają sobie sprawy, iż oklaskują

\footnotetext{
$1 \mathrm{Na}$ temat polityki Rosji wobec Polski z najnowszych badań zob. A. Nowak, Polacy, Rosjanie i biesy, Kraków 1998; L. J. Gorizontow, Paradoksy impierskoj politiki: polaki w Rossii i russkije w Polsze, Moskwa 1999.

${ }_{12} \mathrm{~W}$ czasach radzieckich opera ta zaopatrzona została w ideologicznie zmienione libretto i wystawiano ją pod tytulem Iwan Susanin.
} 
tych, którzy najechali kraj i mają zabić głównego bohatera. Oklaskiwali i oklaskują nadal, wbrew antypolskiej tendencji utworu ${ }^{13}$.

W tych dwóch odbiorach polskości przez społeczeństwo państwowe przejawia się ambiwalencja zaślepionej brakiem samodzielnego myślenia polonofobii i żywiołowej wrażliwości na piękno polonofilii. Razem tworzą ów kompleks nieodwzajemnionej miłości do Polski. Takich Rosjan wciąż uraża brak wzajemności, albowiem poziom myślenia społeczeństwa państwowego i właściwy dlań horyzont wyobrażeń - czyli kultura umysłowa i polityczna, stopień ukształtowania osobowości - to wszystko, co warunkuje oblicze członków tego społeczeństwa, w którym to, co indywidualne, dławione jest przez oficjalne, uniemożliwia zrozumienie mentalności Polaków i należnej skruchy za grzechy państwa rosyjskiego wobec nich.

Zupełnie odrębna sytuacja ma miejsce w sferze społeczeństwa obywatelskiego, gdzie od samego początku nie było powodów na utyskiwanie na „nieodwzajemnioną miłość". Osobiste przyjaźnie Mickiewicza z Rylejewem, Bestużewem, Wiaziemskim, symboliczny pogrzeb pięciu straconych przez cara dekabrystów w wyzwolonej spod władzy Imperium Warszawie podczas powstania listopadowego, słynne hasło „Za Waszą i naszą wolność” czy wiersz Mickiewicza Do przyjaciót Moskali to historyczne już oznaki miłości wzajemnej. Wzajemnej, bo ci Rosjanie i ci Polacy wtedy i dziś, wbrew wszystkim okolicznościom zewnętrznym politycznym, ideologicznym, nacjonalistycznym - posiadają wewnętrzną i dlatego niepodatną na wszelką presję z zewnątrz, wspólną więź, czyli zindywidualizowany, osobowościowy, kulturowy i prawny światopogląd, cechujący społeczeństwo obywatelskie. Tu rodzi się wzajemne rozumienie, empatia, która prowadzi ku sympatii.

Właśnie w ramach społeczeństwa obywatelskiego, wbrew zakrętom historii rosyjskiej, radzieckiej oraz obecnej, przechowuje się tradycja autentycznego rozumienia polskości. Podczas odradzania się społeczeństwa obywatelskiego w czasach Odwilży (po zupełnym rozbiciu go w efekcie przewrotu bolszewickiego) zaczął się również rosyjski renesans polskości. Podobnie jak na początku tworzenia się społeczeństwa obywatelskiego w Rosji, tak i wówczas był to zwrot nie ku polskości jako takiej, zasklepionej w sobie, lecz ku temu, co w obozie socjalistycznym pozostało niepokorne; zwrot ku temu, co wbrew totalitaryzmowi przechowało indywidualność, osobowość, niezależność myślenia, zdolność samodzielnego wyboru i umiejętność podejmowania niewymuszonych decyzji - czyli zwrot ku temu wszystkiemu, co wraz ze społeczeństwem obywatelskim zniszczyli bolszewicy i system władzy radzieckiej. Polonofilstwo w czasach sowieckich oznaczało w istocie - jak w poczatkach wychodzenia z bizantynizmu — otwarcie na Zachód, okcydentalizację przez polonizację. Nakładającym się na to zjawiskiem byla odradzająca się tradycja kulturowo-hi-

\footnotetext{
${ }^{13} \mathrm{Na}$ temat polsko-rosyjskich animozji zob. A. Kępiński, Lach i Moskal. Z dziejów stereotypu, Kraków 1990; J. Orłowski, $Z$ dziejów antypolskich obsesji $w$ literaturze rosyjskiej, Warszawa 1992; A. Lipatow, Obraz Polski i Polaków w sztuce radzieckiej, „Teksty Drugie” 1997 nr 5, s. 25-39; J. Maciejewski, Stereotyp Rosji i Rosjanina $w$ polskiej literaturze i świadomości spotecznej, „Więż” 1998 nr 2, s. 183-197; Polaki i russkije w glazach drug druga, Moskwa 2000; Russkije i polaki: wzaimoponimanije i wzaimonieponimanije, Moskwa [w druku].
} 
storyczna: okcydentalizm w wersji polskiej, $\mathrm{z}$ właściwym mu polskim poczuciem honoru, polskim szacunkiem prawnym dla indywiduum i owym polskim gestem w kulturze codziennej, kojarzył się w czasach Państwa Moskiewskiego z dawną, zniszczoną przez to państwo tradycją demokracji staroruskiej, a dzisiaj - przypomina o zniszczonej przez ZSRR demokratycznej tradycji obywatelskiego społeczeństwa Rosji. A więc przerwana nić historii została związana, nie bez polskiego udziału. Społeczeństwo obywatelskie w obecnej Rosji znów istnieje legalnie, stanowiąc na razie cienką warstwę. Przeważa spoleczeństwo państwowe w swej zsowietyzowanej szacie — takiej samej, jak elita władzy. Stąd w tej warstwie ciagle jest obecna tradycyjna negacja mentalności narodowych w działaniach politycznych, z czego wynika, może nie zawsze uświadomiony, brak szacunku, a więc i zrozumienia narodowych odrębności. Dotyczy to wszystkich, w tym i Polski. Kiedyś znalazło to odbicie w funkcjonującym do dziś pobłażliwie-pogardliwym porzekadle „Kurica nie ptica, Polsza nie zagranica”. Tradycja przypisuje tę perlę wielkomocarstwowej mentalności rosyjskiej pierwszemu imperatorowi Rosji Piotrowi Wielkiemu. Jej zakorzenienie w mentalności rosyjskiej elity władzy trwa do dziś. To między innymi w dostatecznym stopniu ilustruje pozycja dzisiejszej Rosji oficjalnej wobec zagranicznej polityki Polski, która lekkomyślnie zapomniała, że tak naprawdę zagranicą nie jest.

Tradycyjna mentalność elity władzy państwowej utrwala tradycyjny poziom myślenia społeczeństwa państwowego. Płynie stąd brak wyobraźni, co z kolei powoduje brak uświadomienia faktu, że nie tylko wiek XIX, ale również XX już minął. W procesie globalizacji świat się radykalnie zmienił, a razem $z$ nim zmienił się układ sił w Europie i na świecie. Występując przeciwko samodzielnym decyzjom Polski, podobnie jak przeciw innym niezależnym krajom byłego obozu socjalistycznego oraz byłego ZSRR, oficjalna Rosja, nazywająca się demokratyczną, zachowuje się już nie jak mocarstwo (którym być przestała, choć za takie nadal chce siebie uważać), lecz jak porzucona kobieta. W stanie histerii nie chce widzieć, jak żałosne jest jej zachowanie, i nie może zrozumieć, że trzeba wziąć się w garść, żeby ostatecznie się nie zgubić, żeby nie zagnuśnieć, lecz zrozumiawszy samą siebie oprzytomnieć w zmienionej sytuacji, nawiązać nowe stosunki w nowych okolicznościach, wejść w nowe układy, żeby szanując innych uzyskać uszanowanie dla siebie. 